\title{
Effect of exogenous ovine placental lactogen on luteolysis induced by prostaglandin $F-2 \alpha$ in sheep
}

\author{
W. Schramm*†, H. G. Friesen $\ddagger$, H. A. Robertson and J. A. McCracken* \\ *Worcester Foundation for Experimental Biology, Shrewsbury, MA 01545, U.S.A.; \\ \$Department of Physiology, Faculty of Medicine, University of Manitoba, Winnipeg, Manitoba, \\ Canada R3E 0W3; Animal Research Centre, Ottawa, Ontario, Canada K1A OC6
}

\begin{abstract}
Summary. The ability of ovine placental lactogen (oPL) to stimulate progesterone secretion by the ovary as well as its ability to protect the corpus luteum against the luteolytic action of PGF- $2 \alpha$ was investigated. When oPL was infused alone into the ovary for $2 \mathrm{~h}$ on Day 12 of an induced cycle at rates of $0 \cdot 6,6 \cdot 0,30 \cdot 0$ or $60 \cdot 0 \mu \mathrm{g} / \mathrm{h}$ there was no significant increase in progesterone secretion by the autotransplanted ovary in 7 sheep. An extension of the infusion of oPL did not prevent luteal regression during the administration of PGF-2 $\alpha$ given either continuously $(10 \mu \mathrm{g} / \mathrm{h}$ for $6 \mathrm{~h}, 5$ sheep) or as 5 pulses each lasting $1 \mathrm{~h}$ and of increasing concentration in $25 \mathrm{~h} \mathrm{(2} \mathrm{sheep).} \mathrm{We} \mathrm{conclude}$ that oPL does not (a) stimulate progesterone secretion when infused directly into the arterial supply of the ovary or (b) have any direct protective effect against the luteolytic action of PGF- $2 \alpha$ on the ovine CL.
\end{abstract}

\section{Introduction}

The existence of a placental lactogen in sheep was first reported by Kelly, Robertson \& Friesen (1974). These workers demonstrated a rise in ovine placental lactogen (oPL) during pregnancy, which paralleled the increase in progesterone secretion seen at this time. They further suggested that oPL directly stimulates progesterone secretion by the placenta. Subsequent studies revealed that oPL was detectable in the ovine trophoblast as early as Days 14 and 16 of gestation (Carnegie, Chan, Robertson, Friesen \& McCully, 1977; Martal \& Dijane, i 977; Carnegie, Chan, McCully, Robertson \& Friesen, 1982). In addition, the specific binding capacity of oPL is reported to be $6 \%$ for the ovine corpus luteum (CL) and 10\% for the ovary (Chan, Robertson \& Friesen, 1978a) but little is known about its action on the ovary or on placental tissue.

Because of these findings some investigators proposed that oPL might play a role in the maintenance of the CL of early pregnancy (Thorburn, 1977; McCracken, Schramm, Barcikowski \& Wilson, 1981). Amongst various possibilities, we considered that such an effect of oPL could be mediated by a luteotrophic action of $\mathrm{OPL}$ on the $\mathrm{CL}$ of early pregnancy or by a luteoprotective action of oPL against the potential luteolytic effect of prostaglandin (PG) F-2 $\alpha$ on the corpus luteum of early pregnancy. In the present paper, we describe experiments carried out to explore these two possible actions of oPL on the corpus luteum of the sheep.

† Present address: The University of Michigan, 300 North Ingalls, No. 1109 S.W., Ann Arbor, MI 48109, U.S.A. 


\section{Materials and Methods}

\section{Experimental animals}

Merino sheep were used with the left ovary autotransplanted to the neck with anastomoses of the utero-ovarian vein to the jugular vein and the ovarian artery to the carotid artery, these vessels being exteriorized in skin loops as described previously (Goding, McCracken \& Baird, 1967; McCracken, Baird \& Goding, 1971). At the time of transplantation of the left ovary, the right ovary was removed. Since the transplanted ovary in this system is separated from the uterus, the CL persists with a high rate of progesterone secretion. In animals with an actively secreting CL, oestrus was induced by two i.m. injections of $5.0 \mathrm{mg}$ dinoprost (Lutalyse: Upjohn Co., Kalamazoo, MI) a synthetic PGF-2 $\alpha$, administered $4 \mathrm{~h}$ apart (denoted as Day -2). As a check on the effectiveness of treatment with dinoprost, the progesterone concentration was monitored in ovarian venous blood by a semiquantitative method consisting of solvent extraction, thin-layer chromatography and visualization of the progesterone spots under u.v. light.

The day before an infusion experiment a Teflon catheter $(1.5 \mathrm{~mm}$ i.d.) was inserted into the left jugular vein, as described previously (McCracken, Uno, Goding, Ichikawa \& Baird, 1969), for the sampling of ovarian venous blood. For infusion of the ovary, two intra-arterial catheters (Intracath, 20 gauge, $2 \frac{1}{2}$ in., Beckton Dickinson Co., NJ, U.S.A.) were introduced into the left carotid artery, one for infusion of oPL and the other for PGF- $2 \alpha$. To prevent thrombosis after cannulation the sheep were given 5000 i.u. heparin every $4 \mathrm{~h}$ during the course of the experiment. The cannulation was performed on Day 11 of an oestrous cycle induced by dinoprost and the experiments started on Day 12 of this cycle.

\section{Preparation of solutions}

Ovine placental lactogen was isolated and purified according to the methods described previously (Chan et al., 1976, 1978b). A stock solution of $1 \mathrm{mg} \mathrm{oPL} / \mathrm{ml}$ was prepared in sodium chloride solution $(0.9 \mathrm{~g} / \mathrm{l})$, stored at $4^{\circ} \mathrm{C}$ and used within 2 weeks. The biological potency of the oPL preparation used in this study was $36.5 \%$ compared to the most highly purified oPL standard (Chan et al., 1978b).

PGF- $2 \alpha$ as the tham salt and oPL in sterile sodium chloride solution $(0.9 \mathrm{~g} / \mathrm{l})$ were prepared on the day of the experiment. The solutions containing these substances were infused via separate intra-arterial catheters with Harvard infusion pumps at a rate of $3 \mathrm{ml} / \mathrm{h}$ for the periods shown in Text-figs 1 and 2. Ovarian venous blood was collected at intervals of $15 \mathrm{~min}$ or $1 \mathrm{~h}$. After the infusion of oPL was completed blood sampling was continued at $4-\mathrm{h}$ intervals for $72-96 \mathrm{~h}$ after beginning the infusion of PGF- $2 \alpha$.

\section{Infusion experiments}

Two different kinds of infusion experiments were carried out. The first consisted of constant infusion of oPL for $9 \mathrm{~h}$ at 3 different infusion rates: $0.6 \mu \mathrm{g} / \mathrm{h}$ (Ewes 1 and 2), $6 \mu \mathrm{g} / \mathrm{h}$ (Ewes 3 and 4 ) or $60 \mu \mathrm{g} / \mathrm{h}$ (Ewe 5), on which was superimposed an infusion of PGF-2 $\alpha(10 \mu \mathrm{g} / \mathrm{h}$ ) for $6 \mathrm{~h}$ (Text-fig. 1). In the second type of experiment, infusions of PGF- $2 \alpha$ lasting $1 \mathrm{~h}$ were given 5 times in $25 \mathrm{~h}$ in rising concentrations $(0 \cdot 2,0 \cdot 4,0 \cdot 6,0 \cdot 8$ and $1.0 \mu \mathrm{g} / \mathrm{h}$ in Ewe 6, and $0 \cdot 04,0 \cdot 06,0 \cdot 08,0 \cdot 10$ and $0 \cdot 12 \mu \mathrm{g}$ / $\mathrm{h}$ in Ewe 7), superimposed on a continuous infusion of oPL $(30 \mu \mathrm{g} / \mathrm{h}$ for $32 \mathrm{~h}$; Text-fig. 2). In all 7 sheep oPL was infused alone for $2 \mathrm{~h}$ before the infusions of PGF-2 $\alpha$ began.

\section{Blood flow measurement}

Ovarian blood flow was determined by measuring the volume of ovarian venous blood collected per unit time through a wide-bore Teflon cannula in the left jugular vein during occlusion of the upper and lower limbs of the skin loop as described in detail elsewhere (McCracken et al., 1969). 
The Teflon cannula was selected for its ability to accommodate the maximal volume of blood expected to perfuse the ovary. The blood samples were placed on ice immediately after collection, then centrifuged at $4^{\circ} \mathrm{C}$, haematocrits measured, the plasma removed, and stored at $-20^{\circ} \mathrm{C}$ until assay for progesterone and $\mathrm{LH}$ content.

\section{Radioimmunoassays}

Progesterone. The concentration of progesterone in ovarian venous plasma was measured by RIA (Abraham, Swerdloff, Tulchinsky \& Odell, 1970). Because of the high levels of progesterone in ovarian venous plasma, $0.5 \mu \mathrm{l}$ samples of plasma were prepared by serial dilution with phosphate buffer: the dilution minimizes potential interference by plasma proteins and lipids and permits assay for progesterone in unextracted plasma. The concentrations of progesterone in extracted and unextracted plasma samples were in good agreement $(y=0.95 x+0.045$, where $y=\mathrm{ng}$ progesterone extracted and $x=$ ng progesterone unextracted; $r=0.99, P<0.001$ ). Inhibition curves from several dilutions of unextracted plasma were parallel to standard curves. The assay blank was below the limit of detection for the assay. The progesterone antibody was raised in rabbits using pregn-4-ene-11 $\alpha$-ol-3,20-dione hemisuccinate-BSA as the antigen. This conjugated steroid emulsified with Freund's complete adjuvant was injected subcutaneously in male rabbits on 3 separate occasions at a dose of $2 \mathrm{mg} /$ animal using at least 6 different sites for injection. The rabbits were bled at intervals of 1 month for 3 months. At $70 \%$ binding the cross-reactivity of the antibody for the following steroids was: $17 \alpha$-hydroxyprogesterone $0.1 \%, 11 \alpha$-hydroxyprogesterone

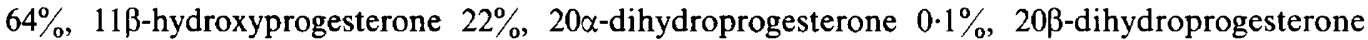
$0.1 \%$, cholesterol $0.1 \%$, deoxycorticosterone $1 \%$, ostrone $0.1 \%$, oestriol $0.1 \%$, oestradiol $0.1 \%$, testosterone $0.1 \%$, pregnenolone $0.1 \%$. At the lower part of the standard curve $(30 \mathrm{pg})$ the intra- and inter-assay coefficients of variation were $9.3 \%$ and $19 \cdot 2 \%$, respectively $(n=10)$.

In addition to the above assay, the concentration of progesterone in plasma pools, using both unextracted and extracted samples, was checked routinely with a commercially available RIA kit (NEN; Boston, MA). The results were in good agreement (correlation coefficient $=0.99, P<$ 0.001 ). The secretion rate of progesterone at each sampling time was calculated by multiplying the concentration of progesterone in each sample ( $\mu \mathrm{g} / \mathrm{ml}$ plasma) by the volume of plasma present in each timed blood sample, i.e. secretion rate per minute $=$ concentration of progesterone $(\mu \mathrm{g} / \mathrm{ml}) \times$ plasma flow (ml/min).

Luteinizing hormone. A highly specific antibody against LH (first antibody) was raised in rabbits, as described by Scaramuzzi, Caldwell \& Moor (1970). With a final antibody dilution of $1: 100000$, binding of about $50 \%$ of the labelled hormone was obtained. For precipitation of the soluble LH-anti-LH complex, anti-rabbit gamma globulin (second antibody) was raised in female goats by repeated injections of the rabbit gamma globulin, emulsified in Freund's complete adjuvant using standard immunological procedures and schedules.

Iodination of purified ovine LH, LER-1056-C2, kindly supplied by Dr L. E. Reichert (Reichert, 1966) was performed with thiosulphate-free $\mathrm{Na}^{125}$ I (Amersham, IL, U.S.A.) and chloramine-T at pH 7.8 in 0.01 M-phosphate buffer, according to the method of Greenwood, Hunter \& Glover (1963). Iodinated LH was separated from free iodine by column chromatography on Sephadex G-50, conditioned with $2 \% \mathrm{BSA}$ in phosphate buffer, and eluted with $1 \% \mathrm{BSA}-0.01 \mathrm{M}$-EDTA in phosphate buffer. Iodinated LH was stored at $4^{\circ} \mathrm{C}$ and used within 1 week without further purification. After 1 week, remaining labelled $\mathrm{LH}$ was re-chromatographed and used for another assay.

The radioimmunoassay was performed as described by Niswender, Reichert, Midgley \& Nalbandov (1969), with some modifications. For competition with the unlabelled hormone a total of about $30000-50000$ c.p.m. radiolabelled LH was used. There was a linear dose-response relationship between $100 \mathrm{pg}$ and $12.8 \mathrm{ng}$ of $\mathrm{LH}$, after logit-log transformation (Midgley, Niswender \& Rebar, 1969). By serial dilution of an ovine plasma sample (125 $\mathrm{ng} \mathrm{LH} / \mathrm{ml})$ an inhibition curve 
with a slope parallel to the standard curve was obtained. Addition of graded amounts of exogenous LH to plasma of a hypophysectomized sheep resulted in a curve of slope 0.93 (abscissa: ng LH measured, ordinate: $\mathrm{ng} \mathrm{LH}$ added). The coefficient of variation for recovery was $16.4 \%$, intra-assay variation at $5 \mathrm{ng} \mathrm{LH} / \mathrm{ml}$ was $9 \cdot 3 \%(n=12)$, and inter-assay variation at the same concentration was $15.4 \%(n=12)$. Cross-reactivity with FSH at $70 \%$ binding was $<0.1 \%$. The limit of detection for the $\mathrm{LH}$ assay was $0.08-0.1 \mathrm{ng} /$ tube.

\section{Statistics}

The data were evaluated by one-way analysis of variance by allowing a $90 \%$ confidence level as acceptance region for the F-function.
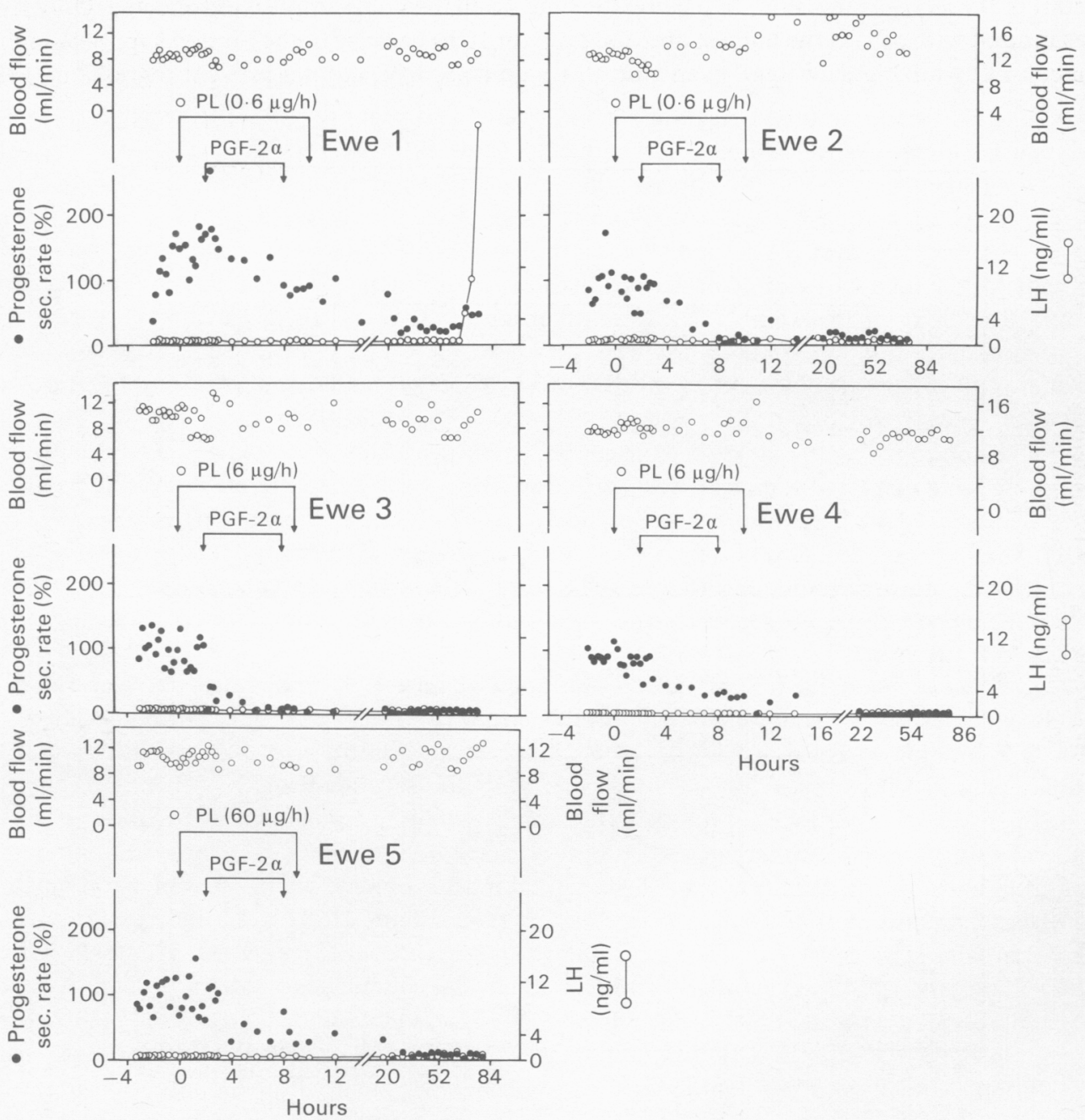

Text-fig. 1. The effect of an infusion of PGF- $2 \alpha(10 \mu \mathrm{g} / \mathrm{h}$ for $6 \mathrm{~h})$ superimposed on $10-\mathrm{h}$ infusion of oPL $(0.6 \mu \mathrm{g} / \mathrm{h}$ for Ewes 1 and 2, 6.0 $\mu \mathrm{g} / \mathrm{h}$ for Ewes 3 and $4,60 \mu \mathrm{g} / \mathrm{h}$ for Ewe 5), both given into the arterial supply of the autotransplanted ovary on Day 12 of an induced cycle. Progesterone secretion rate (O), expressed as a percentage of controls, and $\mathrm{LH}(\mathrm{O}-\mathrm{O}, \mathrm{ng} / \mathrm{ml})$ were measured throughout each experiment. Blood flow $(\mathrm{O}, \mathrm{ml} / \mathrm{min})$ from the ovarian transplant was also recorded. 


\section{Results}

The administration of highly purified oPL alone for $2 \mathrm{~h}$ at 4 different infusion rates $(0 \cdot 6,6 \cdot 0,30 \cdot 0$ and $60 \cdot 0 \mu \mathrm{g} / \mathrm{h}$ ) into the arterial supply of the transplanted ovary containing a functional CL did not increase significantly the secretion rate of progesterone at any of the rates employed. The mean \pm s.e.m. secretion rate of progesterone in the 7 sheep during the control period was $6 \cdot 2 \pm 0 \cdot 32 \mu \mathrm{g} / \mathrm{min}$.

Ovine placental lactogen did not prevent a fall in the secretion rate of progesterone when a known luteolytic dose of PGF-2 $\alpha$ was given as a continuous infusion $(10 \mu \mathrm{g} / \mathrm{h}$ for $6 \mathrm{~h})(\mathrm{Text}-\mathrm{fig} .1)$. Regression of the CL occurred with this dose of PGF- $2 \alpha$ in all cases, even though the doses of oPL infused concurrently covered a very wide range $(0 \cdot 6-60 \cdot 0 \mu \mathrm{g} / \mathrm{h})$. There was no detectable LH surge after luteal regression in Ewes 2, 3, 4 and 5, but the beginning of an LH peak was detected in Ewe 1 (Text-fig. 1). In this ewe, LH values were 5,10 and $34 \mathrm{ng} / \mathrm{ml}$ at 68,72 and $76 \mathrm{~h}$, respectively, after the start of the PGF- $2 \alpha$ infusion, $76 \mathrm{~h}$ being the time when the final sample was collected. Only Ewe 5 was infused with oPL at the highest dose $(60 \mu \mathrm{g} / \mathrm{h}$ for $10 \mathrm{~h})$ because of the limited supply of highly purified oPL available. However, even with this high dose, oPL did not prevent regression of the CL.

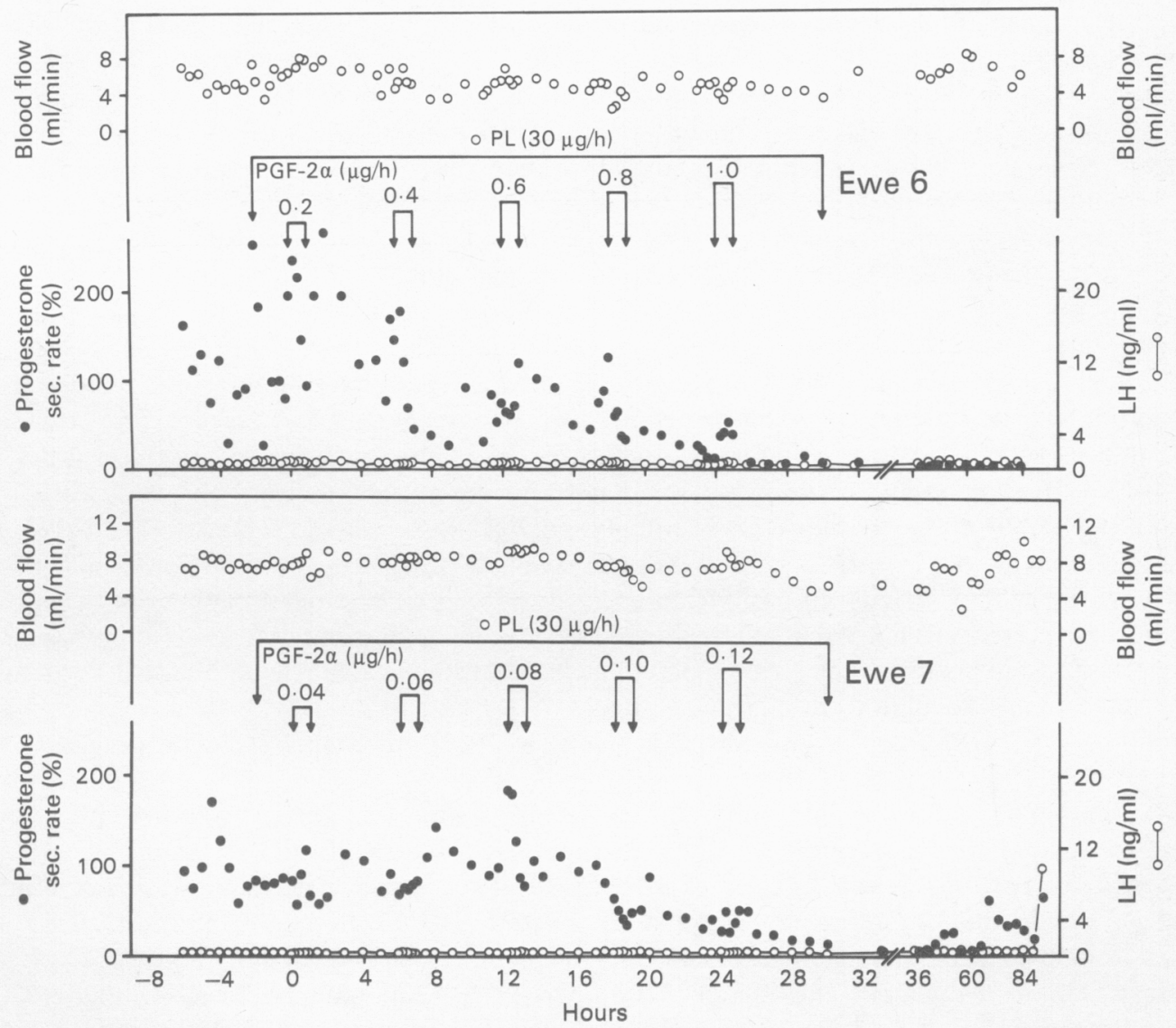

Text-fig. 2. The effect of 5 infusions of PGF-2 $\alpha$ each lasting $1 \mathrm{~h}$ and given in increasing concentrations superimposed on an infusion of oPL $(30 \mu \mathrm{g} / \mathrm{h}$ for $32 \mathrm{~h})$ both given into the arterial supply of the autotransplanted ovary in Ewes 6 and 7 on Day 12 of an induced cycle. Progesterone secretion rate (O), expressed as a percentage of controls, and $\mathrm{LH}(\mathrm{O}-\mathrm{O}, \mathrm{ng} /$ $\mathrm{ml})$ were measured throughout each experiment. Blood flow $(0, \mathrm{ml} / \mathrm{min})$ from the ovarian transplant was also recorded. 
In the two experiments with Ewes 6 and 7 in which PGF- $2 \alpha$ was administered, to simulate physiological conditions, in the form of 5 pulses lasting $1 \mathrm{~h}$ and of increasing magnitude over $25 \mathrm{~h}$ (Text-fig. 2), oPL infused concurrently $(30 \mu \mathrm{g} / \mathrm{h}$ for $32 \mathrm{~h}$ ) again did not prevent a fall in progesterone secretion rate. Such a regimen has been shown previously to cause luteal regression consistently in the autotransplanted ovary (Schramm, Bovaird, Glew \& McCracken, 1982). In only one of the pulsed infusion experiments was the beginning of an LH peak detected (Ewe 7; Text-fig. 2). The $\mathrm{LH}$ concentration was $<1.0 \mathrm{ng} / \mathrm{ml}$ at $88 \mathrm{~h}$ after the start of the infusion of PGF-2 $\alpha$ and had risen to $10.4 \mathrm{ng} / \mathrm{ml}$ in the final sample at $92 \mathrm{~h}$. In Ewe 6 (Text-fig. 2) sampling was terminated at $84 \mathrm{~h}$ and no LH rise was detected by that time.

\section{Discussion}

Because of the parallel rise of oPL and progesterone levels during gestation in the sheep (Kelly et al., 1974) and the presence of oPL in the early sheep trophoblast (Carnegie et al., 1977, 1982; Martal \& Dijane, 1977), it was considered that oPL might have a luteotrophic action. Such a possibility was further supported by the fact that oPL binds specifically to ovine CL membrane fractions (Chan et al., 1978a). Until the present work, no systematic studies had been carried out to investigate whether oPL actually stimulates progesterone secretion in vivo. However, the results of this study have shown that, on Day 12 of an induced cycle, oPL treatment of the ovary for $2 \mathrm{~h}$ does not increase significantly the secretion of progesterone by the CL. This finding is supported by all of the experiments described in this paper, including the data from Ewe 1 (Text-fig. 1), because the high fluctuation of progesterone output in this animal was not considered to represent an effect of oPL since such an episodic release of progesterone is occasionally observed during control periods in some animals (Schramm et al., 1982). A similar episodic release of progesterone in sheep has been reported by Niswender, Moore, Akbar, Nett \& Diekman (1975).

Ellinwood, Nett \& Niswender (1979) were unable to demonstrate a stimulatory effect of homogenates of Day 14-15 ovine embryos on progesterone production or cAMP levels in dispersed ovine luteal cells in vitro. However, R. T. Duby \& H. B. Ernst (personal communication) found that homogenates of ovine embryos did have luteotrophic actions on ovine luteal tissue in vitro, provided that the extract was not frozen before incubation, as was done by Ellinwood et al. (1979). The identity of this apparently labile substance is not known at present. From our results, oPL is unlikely to be responsible for the observed stimulation. Beal, Lukaszewska \& Hansel (1981) showed that homogenates and extracts of bovine embryos stimulate progesterone production by dispersed bovine luteal cells. The ovine corpus luteum normally persists throughout pregnancy in the sheep although its presence is not essential after Day 50 (Heap, 1972). It is possible, therefore, that oPL may play a role in pregnancy by forming part of a placental complex which, with hCG-like factors that have been isolated from placental tissues of both sheep (Martal \& Lacroix, 1978; Wintenberger, 1978) and cow (Ailenberg \& Shemesh, 1983), maintains placental progesterone synthesis.

Besides having a luteotrophic action, the early embryo appears to have two other effects: (a) suppression of PGF-2 $\alpha$ secretion (sheep: Thorburn, Cox, Currie, Restall \& Schneider, 1973; Barcikowski, Carlson, Wilson \& McCracken, 1974; Peterson, Tervit, Fairclough, Havik \& Smith, 1976; cow: Kindahl, Granström, Edqvist \& Eneroth, 1976a; Kindahl, Edqvist, Bane \& Granström, 1976b; gilt: Moeljono et al., 1977; Shille et al., 1979) and (b) a luteoprotective effect against PGF-2 $\alpha$ (Mapletoft, Del Campo \& Ginther, 1975; Mapletoft, Lapin \& Ginther, 1976; Pratt, Butcher \& Inskeep, 1977; Huie et al., 1981). As well as studying a possible luteotrophic action of $\mathrm{oPL}$, the other objective of the present study was to investigate in detail the potential luteoprotective properties of oPL. All the results indicate that there is no protective effect of oPL on the CL against the luteolytic action of PGF- $2 \alpha$, despite the wide range of concentration of oPL or PGF- $2 \alpha$ infused. Also, very low physiological concentrations of PGF- $2 \alpha$, given as 5 pulses over $25 \mathrm{~h}$ and a comparatively high infusion rate of oPL $(30 \mu \mathrm{g} / \mathrm{h})$ resulted in luteal regression (Text-fig. 2). 
The pulsatile infusion of PGF- $2 \alpha$ was implemented because this type of intermittent pattern is more representative of the physiological condition with respect to the levels of PGF- $2 \alpha$ reaching the ovary during naturally occurring luteolysis (Schramm et al., 1982). In this series of experiments there was evidence of an LH peak in only 2 animals, probably because, with the lower doses of PGF- $2 \alpha$, the LH peak occurs considerably later than when higher doses of PGF- $2 \alpha$ are used. For example, with infusion rates of about $50 \mu \mathrm{g}$ PGF- $2 \alpha / \mathrm{h}$ the LH peak occurred within $72 \mathrm{~h}$ after infusion (McCracken, Glew \& Scaramuzzi, 1970; Chamley et al., 1972). Had sampling been continued for a longer period it is likely that an LH peak would have been detected in most, if not all, animals, as found in studies with very low pulsed doses of PGF-2 $\alpha(0.04-2 \cdot 0 \mu \mathrm{g} / \mathrm{h})(\mathrm{Schramm}$ et al., 1982). On the other hand, we are not able to exclude the possibility that oPL could have delayed the LH peak, perhaps by retarding follicular growth and hence oestradiol-17 $\beta$ secretion which was not measured in this study.

Although ovine pituitary LH stimulates progesterone secretion when infused into the transplanted ovary of the sheep, ovine prolactin has essentially no effect (McCracken et al., 1969). However, neither LH nor prolactin infused into the transplanted ovary consistently protected the ovine corpus luteum against the luteolytic action of administered PGF- $2 \alpha$ (McCracken, Barcikowski, Carlson, Greeen \& Samuelsson, 1973). There is evidence in luteal homogenates from pseudopregnant rats that oPL, like ovine prolactin, will maintain LH receptors but does not prevent the fall in progesterone levels induced by PGF- $2 \alpha$ (Chan, Grinwich, Robertson \& Friesen, 1980 ). Thus the inability of oPL to prevent the fall in progesterone induced with PGF- $2 \alpha$ in the present study is in agreement with the findings in the pseudopregnant rat. Moreover the results in both the rat and the sheep support the concept that the luteolytic action of PGF-2 $\alpha$ occurs at a site beyond the $\mathrm{LH}$ receptor (Henderson \& McNatty, 1975). The observed absence of a luteoprotective effect of oPL is supported by the studies of Martal, Lacroix, Loudes, Saunier \& WintenbergerTorrès (1979) who injected oPL into the uterine lumen of cyclic sheep but observed no delay in the onset of luteal regression. However, Martal et al. (1979) administered oPL by an intrauterine route (intra-ovarian in the present study) and gave $40-50 \mu \mathrm{g}$ oPL as a single daily injection. Hence the results of these two studies are not strictly comparable.

Although oPL has been detected in the sheep trophoblast as early as Days 14-16 of pregnancy (Carnegie et al., 1977, 1982; Martal \& Dijane, 1977), its concentration in uterine venous plasma before Day 40 of pregnancy is below the limit of detection $(<1.0 \mathrm{ng} / \mathrm{ml})$ (Chan et al., 1978b). At the maximum infusion rate of oPL used in the present study $(60 \mu \mathrm{g} / \mathrm{h})$ and a maximum blood flow in the transplanted ovary of about $10 \mathrm{ml} / \mathrm{min}$, the maximum concentration of biologically active oPL (based on $36.5 \%$ potency) in blood reaching the ovary would be in the order of $33 \mathrm{ng} / \mathrm{ml}$. Such levels would not be found in peripheral blood until much later in pregnancy in the sheep (Chan et al., $1978 \mathrm{~b}$ ). It could be argued that high concentrations of oPL in the ovary or CL could result from selective uptake or binding or even by a local transfer mechanism from the uterus to the ovary. However, even if such concentrating mechanisms exist for oPL in the corpus luteum, according to the results of the present study, oPL would exert neither a luteotrophic nor a luteoprotective action on the corpus luteum. The possibility that oPL contributes to the maintenance of early pregnancy in sheep by a local inhibitory action on the secretion of PGF- $2 \alpha$ by the uterus remains to be investigated.

We thank Merrilyn E. Glew, Larry Bovaird and Lawrence F. Underwood for expert laboratory and surgical assistance; Dr J. Pike, Dr J. Lauderdale and Dr P. O'Connell (Upjohn) for PGF-2 $\alpha$, Lutalyse (dinoprost) and heparin, respectively; Dr H. Esber (EG \& G, Mason Research) for the antibodies to progesterone and ovine LH; Dr L. E. Reichert for purified ovine LH for iodination; Dr C. Kaltenbach for plasma from an hypophysectomized sheep; and Gudrun Schramm for the illustrations.

This study was supported by USPHS Grant No. HD 08129 and a Research Fellowship (W.S.) from the Deutsche Forschungsgemeinschaft. Animal Research Centre Contribution No. 1126. 


\section{References}

Abraham, G.E., Swerdloff, R., Tulchinsky, D. \& Odell, W.D. (1970) Radioimmunoassay of progesterone. $J$. clin. Endocr. Metab. 32, 619-624.

Ailenberg, M. \& Shemesh, M. (1983) Partial purification of a chorionic gonadotropin-like protein from bovine cotyledons. Biol. Reprod. 28, 517-522.

Barcikowski, B., Carlson, J.C., Wilson, L. \& McCracken, J.A. (1974) The effect of endogenous and exogenous estradiol-17 $\beta$ on the release of prostaglandin $F_{2 \alpha}$ from the ovine uterus. Endocrinology 95, 1340-1349.

Beal, W.E., Lukaszewska, J.H. \& Hansel, W. (1981) Luteotropic effects of bovine blastocysts. J. Anim. Sci. 52, 567-574.

Carnegie, J.A., Chan, J.S.D., Robertson, H.A., Friesen, H.G. \& McCully, M.E. (1977) Placental lactogen in the preattachment sheep embryo. J. Anim. Sci. 45, Suppl. 1, 142, Abstr. 359.

Carnegie, J.A., Chan, J.S.D., McCully, M.E., Robertson, H.A. \& Friesen, H.G. (1982) The cellular localization of chorionic somatomammotrophin in ovine chorion. J. Reprod. Fert. 66, 9-16.

Chamley, W.A., Buckmaster, J.M., Cain, M.D., Cerini, J., Cerini, M.E., Cumming, I.A. \& Goding, J.R. (1972) The effect of prostaglandin $F_{2 \alpha}$ on progesterone, oestradiol and luteinizing hormone secretion in sheep with ovarian transplants. $J$. Endocr. 55, 253-263.

Chan, J.S.D., Robertson, H.A. \& Friesen, H.G. (1976) The purification and characterization of ovine placental lactogen. Endocrinology 98, 65-76.

Chan, J.S.D., Robertson, H.A. \& Friesen, H.G. (1978a) Distribution of binding sites for ovine placental lactogen in sheep. Endocrinology 102, 632-640.

Chan, J.S.D., Robertson, H.A. \& Friesen, H.G. (1978b) Maternal and fetal concentration of ovine placental lactogen measured by radioimmunoassay. Endocrinology 102, 1606-1613.

Chan, J.S.D., Grinwich, D.L., Robertson, H.A. \& Friesen, H.G. (1980) Maintenance of receptors for luteinizing hormone by ovine placental lactogen in pseudopregnant rats. Biol. Reprod. 23, 60-63.

Ellinwood, W.E., Nett, T.M. \& Niswender, G.D. (1979) Maintenance of the corpus luteum of early pregnancy in the ewe. I. Luteotropic properties of embryonic homogenates. Biol. Reprod. 21, 281-288.

Goding, J.R., McCracken, J.A. \& Baird, D.T. (1967) The study of ovarian function in the ewe by means of a vascular autotransplantation technique. $J$. Endocr. $39,37-52$.

Greenwood, F.C., Hunter, W.M. \& Glover, J.S. (1963) The preparation of 131 I-labelled human growth hormone of high specific radioactivity. Biochem. $J$. 89, $114-123$.

Heap, R.B. (1972) Role of hormones in pregnancy. In Reproduction in Mammals, Vol. 3, Hormones in Reproduction, pp. 73-105. Eds C. R. Austin \& R. V. Short. Cambridge University Press

Henderson, K.M. \& McNatty, K.P. (1975) A biochemical hypothesis to explain the mechanism of luteal regression. Prostaglandins 9, 779-797.

Huie, J.M., Magness, R.R., Reynolds, L.P., Hoyer, G., Hueckstaedt, T., Colcord, M., Stalcup, B., Whysong, G.L. \& Weems, C.W. (1981) Effects of chronic ipsilateral intrauterine infusion of prostaglandin $E_{\text {, }}$ $\left(\mathrm{PGE}_{1}\right)$ on luteal function of unilaterally ovariectomized ewes. Prostaglandins 21, 945-955.

Kelly, P.A., Robertson, H.A. \& Friesen, H.G. (1974) Temporal pattern of placental lactogen and progesterone secretion in sheep. Nature, Lond. 248, 435437.

Kindahl, H., Granström, E., Edqvist, L.E. \& Eneroth, P. (1976a) Prostaglandin levels in peripheral plasma during the reproductive cycle. Adv. Prostaglandin and Thromboxane Res. 2, 667-671.

Kindahl, H., Edqvist, L.-E., Bane, A. \& Granström, E. (1976b) Blood levels of progesterone and 15-keto13,14-dihydroprostaglandin $F_{2 \alpha}$ during the normal oestrous cycle and early pregnancy in heifers. Acta endocr., Copenh. 82, 134-149.

Mapletoft, R.J., Del Campo, M.R. \& Ginther, O.J. (1975) Unilateral luteotropic effect of uterine venous effluent of a gravid uterine horn in sheep. Proc. Soc. exp. Biol. Med. 150, 129-133.

Mapletoft, R.J., Lapin, D.R. \& Ginther, O.J. (1976) The ovarian artery as a final component of the local luteotropic pathway between a gravid uterine horn and ovary in ewes. Biol. Reprod. 15, 414-421.

Martal, J. \& Dijane, J. (1977) The production of chorionic somatomammotrophin in sheep. J. Reprod. Fert. 49, 285-289.

Martal, J. \& Lacroix, M.C. (1978) Importance d'une trophoblastine dans le controle endocrinien du corps jaune gestatif chez la Brebis, au moment de l'implantation. In Implantation de l'Oeuf, pp. 193-208. Eds F du Mesnil du Buisson, A. Psychoyos \& K. Thomas. Masson, Paris.

Martal, J., Lacroix, M.-C., Loudes, C., Saunier, M. \& Wintenberger-Torrès, S. (1979) Trophoblastin, an antiluteolytic protein in early pregnancy in sheep. $J$. Reprod. Fert. 56, 63-73.

McCracken, J.A., Uno, A., Goding, J.R., Ichikawa, Y. \& Baird, D.T. (1969) The in vivo effects of sheep pituitary gonadotrophins on the secretion of steroids by the autotransplanted ovary of the ewe. J. Endocr. 45, 425-440.

McCracken, J.A., Glew, M.E. \& Scaramuzzi, R.J. (1970) Corpus luteum regression induced by prostaglandin $\mathrm{F}_{2 \alpha}$. J. clin. Endocr. Metab. 30, 544-546.

McCracken, J.A., Baird, D.T. \& Goding, J.R. (1971) Factors affecting the secretion of steroids by the transplanted ovary in the sheep. Recent Prog. Horm. Res. 27, 537-582.

McCracken, J.A., Barcikowski, B., Carlson, J.C., Gréen, K. \& Samuelsson, B. (1973) The physiological role of prostaglandin $\mathrm{F}_{2 \alpha}$ in corpus luteum regression. $A d v$. Biosci. 9, 599-624.

McCracken, J.A., Schramm, W., Barcikowski, B. \& Wilson, L. (1981) The identification of prostaglandin $F_{2 x}$ as a uterine luteolytic hormone in sheep and the endocrine control of its synthesis. Acta vet. scand., Suppl. 77, 71-88.

Midgley, A.R., Jr, Niswender, G.D. \& Rebar, R.W. (1969) Principles for the assessment of the reliability of radioimmunoassay. Acta endocr., Copenh., Suppl. 142, 163-184. 
Moeljono, M.P.E., Thatcher, W.W., Bazer, F.W., Frank, M., Owens, L.J. \& Wilcox, C.J. (1977) A study of prostaglandin $\mathrm{F}_{2 \alpha}$ as the luteolysin in swine. II. Characterization and comparison of prostagland in $F$, estrogens and progestin concentrations in uteroovarian vein plasma of nonpregnant and pregnant gilts. Prostaglandins 14, 543-555.

Niswender, G.D., Reichert, L.E., Jr, Midgley, A.R., Jr \& Nalbandov, A.V. (1969) Radioimmunoassay for bovine and ovine luteinizing hormone. Endocrinology 84, $1166-1173$

Niswender, G.D., Moore, R.T., Akbar, A.M., Nett, T.M. \& Diekman, M.A. (1975) Flow of blood to the ovaries of ewes throughout the estrous cycle. Biol. Reprod. 13, 381-388.

Peterson, A.J., Tervit, H.R., Fairclough, R.J., Havik, P.G. \& Smith, J.F. (1976) Jugular levels of 13,14dihydro-15-keto-prostaglandin $F$ and progesterone around luteolysis and early pregnancy in the ewe. Prostaglandins 12, 551-558.

Pratt, B.R., Butcher, R.L. \& Inskeep, E.K. (1977) Antiluteolytic effect of the conceptus and of $\mathrm{PGE}_{2}$ in ewes. J. Anim. Sci. 46, 784-791.

Reichert, L.E., Jr (1966) Characterization of purified heterologous pituitary luteinizing hormones by dini- trophenylation, digestion with carboxypeptidase A and hydrazinolysis. Endocrinology 78, 186-194.

Scaramuzzi, R.J., Caldwell, B.V. \& Moor, R.M. (1970) Radioimmunoassay of $\mathrm{LH}$ and estrogen during the estrous cycle of the ewe. Biol. Reprod. 3, 110-119.

Schramm, W., Bovaird, L., Glew, M.E. \& McCracken, J.A. (1982) Corpus luteum regression induced by ultra-low pulses of prostaglandin $\mathrm{F}_{2 \alpha}$. Proc. 5 th Int. Conf. Prostaglandins, Italy, Abstr. 385.

Shille, V.M., Karlbom, I., Einarsson, S., Larsson, K., Kindahl, H. \& Edqvist, L.E. (1979) Concentrations of progesterone and 15-keto-13,14-dihydroprostaglandin $\mathbf{F}_{2 \alpha}$ in peripheral plasma during the estrous cycle and early pregnancy in gilts. Zentbl. VetMed. A 126, 169-181.

Thorburn, G.D. (1977) Fetus, pregnancy and parturition Annls Rech. Vet. 8, 428-437.

Thorburn, G.D., Cox, R.I., Currie, W.B., Restall, B.J. \& Schneider, W. (1973) Prostaglandin F and progesterone concentrations in the utero-ovarian venous plasma of the ewe during the oestrous cycle and early pregnancy. J. Reprod. Fert., Suppl. 18, 151-158.

Winterberger, S. (1978) Role actif de l'embryon avant l'implantation. In Implantation de l'Oeuf, pp. 181192. Eds F. du Mesnil du Buisson, A. Psychoyos \& K. Thomas. Masson, Paris.

Received 13 July 1983 